\title{
VIETNAM IN THE GLOBAL GARMENT AND TEXTILE VALUE CHAIN: IMPACTS ON FIRMS AND WORKERS
}

\author{
KHALID NADVI $^{1}$ and JOHN T. THOBURN ${ }^{2 *}$ \\ with BUI TAT THANG ${ }^{3}$, NGUYEN THI THANH HA ${ }^{3}$, \\ NGUYEN THI HOA ${ }^{4}$, DAO HONG LE ${ }^{5}$ and ENRIQUE BLANCO DE ARMAS ${ }^{4}$ \\ ${ }^{1}$ Institute of Development Studies, University of Sussex, Brighton, UK \\ ${ }^{2}$ School of Development Studies, University of East Anglia, Norwich, UK \\ ${ }^{3}$ Institute of Economics, Hanoi \\ ${ }^{4}$ Institute of Social Sciences, Ho Chi Minh City \\ ${ }^{5}$ Co-ordination Centre for Poverty Reduction, Hanoi
}

\begin{abstract}
Over the course of little more than a decade, Vietnam has become a significant exporter of garments to the EU and Japan, and now to the US too. Based on interviews with firms and buyers, and analysis of trade data, this paper traces how Vietnamese garment and textile firms are inserted into global garment and textile value chains. It considers ties between the Vietnamese garment and textiles industries. And, it reflects on how the nature of insertion into global value chains leads to differentiated gains for state owned and private enterprises, and for textile and garment workers. Copyright (C) 2004 John Wiley \& Sons, Ltd.
\end{abstract}

\section{INTRODUCTION}

Understanding the relationship between globalization and poverty is not only the central theme for this special issue, it is the core agenda in development policy research (Stiglitz, 2002; DfID, 2000). The textiles and garment (T\&G) industries, the quintessential engines of industrial growth for many developing countries, provide an obvious entry point for such an enquiry. The attraction of these industries for many developing countries includes their low capital set up costs and their reliance on low skilled and cheap, often women, workers. Thus, in many developing countries, $T \& G$ account for a significant share of manufacturing employment and value added. These sectors also exemplify the opportunities - and threats - from globalization. Built up under import substituting (textiles) and export-led (garments) strategies, they have had to adjust to trade liberalization and to changing global competition. An important aspect of the 'new' competition is the

*Correspondence to: Dr J. T. Thoburn, School of Development Studies, University of East Anglia, NR4 7TJ Norwich. E-mail: j.t.thoburn@uea.ac.uk 
impending phase out of the Multi-Fibre Arrangement (MFA), the regime governing international trade in textiles and clothing. Accompanying the changing trade regime is increasing competition from China. Also, there are pressures to meet international labour and environmental standards, and demands from global buyers for cheaper products, higher quality, and shorter lead times. Adjustments arising from such global challenges can have significant local effects.

Vietnam provides a valuable case for studying the differential gains from globalization for garment and textiles firms and workers. Over the past decade it has emerged as one of the fastest growing garment exporters. Textiles and garments, with exports totalling some US\$ 2.7 billion in 2002, account for about half of Vietnam's manufactured exports ${ }^{1}$ and Vietnam has emerged as a leading supplier to quality conscious markets in Japan and Western Europe. With the coming into force of the bilateral trade agreement with the United States (USBTA) in December 2001, it is becoming a major supplier to the US, the world's largest garment market. This paper seeks to understand the basis of this success by tracing how Vietnam is inserted into global garment and textiles value chains.

Although a centrally planned economy, Vietnam began liberalizing with the doi moi ('renovation') reforms in1986. This has meant '... a shift in investment toward labour intensive manufacturing activities in general and a shift to manufactured exports in particular' (World Bank Vietnam, 2000, p. 12). T\&G are core elements of Vietnam's export led industrial policy. Under an ambitious strategy announced in 1998, export earnings from $T \& G$ are planned to more than quadruple between 2000 and 2010, and employment to nearly triple (Bui, 2001). This is no easy task. To begin with, Vietnam has had to reorient its $\mathrm{T} \& \mathrm{G}$ exports following the collapse of its major markets in the former USSR and Eastern Europe in late 1980s and early 1990s (Hill, 2000). Second, it has until recently been excluded from the largest global consumer market for garments, the United States. Third, it has a significant state enterprise sector which itself is under a process of restructuring. Finally, it is a 'latecomer' to export garment manufacture.

Engagement in global garment markets has significant implications for poverty reduction in Vietnam through potential employment expansion. Vietnam also has a large textiles industry alongside its garment sector. This raises questions on whether linkages with the local textiles sector improves competitiveness and offers opportunities for upgrading. Finally, it is important to note that the industry is heterogeneous, with state owned enterprises, private firms, and wholly, or partially, foreign-invested enterprises. Ties to global markets and their implications for local employment are likely to differ for these distinct types of firms.

Value chain analysis has been widely used in investigating global production and trade in garments (Gereffi, 1999; Bair and Gereffi, 2001). One reason for this is the importance of international retailers and global buyers in determining and organizing the insertion of developing country firms into global garment markets. This is the archetypal buyer-driven industry, where consumer demands change rapidly with new fashion trends and international retailers respond by organizing production networks of dispersed global producers. According to this model, it is the nature of insertion into global value chains that influences the functions that local firms can undertake in textile and garment production. It also effects options for upgrading available to local producers, and their ability to capture a larger share of value added.

\footnotetext{
${ }^{1}$ Proportion of total exports from STAR (2003: 104). Absolute export figure from http://just-style.com, accessed May 2003.
} 
This paper documents how Vietnamese firms are inserted into global garment and textile value chains. It also considers the ties between the Vietnamese garment and textiles industries. Finally, it reflects on how the nature of insertion into global value chains varies between state-owned and private enterprises, and considers the consequences of this for workers. The following section gives an overview of Vietnam's garment and textiles industry and uses international trade data to map Vietnam's changing position in its leading export markets. Section 3 draws on primary evidence from firms and global buyers to observe how Vietnamese firms are inserted into global value chains. Section 4 outlines the differentiated gains, distinguishing winners and losers amongst firms and workers. Section 5 concludes.

\section{VIETNAM'S TEXTILES AND GARMENT INDUSTRY - AN OVERVIEW}

While primary commodities (rice, coffee and marine products) dominate Vietnam's exports, textiles and clothing constituted around half of Vietnam's total manufactured exports in the 1990s. T\&G exports also grew faster than the country's total exports, achieving a remarkable average annual growth rate of 29 per cent from 1991 to $2000 .^{2}$

There are important differences, as well as notable connections, between the Vietnamese garments and textiles sectors. The garment sector is predominantly exportoriented whereas Vietnamese textiles are primarily sold in the domestic market. The share of textiles in total textiles and garment exports fell to under 12 per cent by 1998 (Table 1). ${ }^{3}$ According to the latest (1996) input-output table, only 11.3 per cent of total gross textile output was directly exported, compared with 84 percent of total garment production. While textile imports were the equivalent of 77 per cent of gross textile output, clothing imports were the equivalent of 21.8 per cent of the gross output of clothing. This points to the importance of imported textiles for export garment production (see Hill, 2000; Vu et al., 2001b), although as we show below, some textile SOEs have developed garment exports using their own fabrics.

Textiles and garment firms also differ significantly in terms of their size and ownership profile. Half of Vietnam's textile production in 1998 was from state-owned enterprises (SOEs), predominantly those controlled by central government. In contrast, SOEs accounted for only 30 per cent of garment output in 1998. During the latter part of the 1990 s, 100 per cent foreign invested units have begun to account for a greater share of total

Table 1. Vietnam textile and garment export shares

\begin{tabular}{lll}
\hline Shares $(\%)$ & 1990 & 2001 \\
\hline Textiles and garments in total exports & 7.9 & 13.3 \\
Textiles and garments in total manufacturing exports & 56 & 45 (garments alone) \\
Textiles in total textile and garments exports & 23.5 & 11.8 (1998 figure) \\
\hline
\end{tabular}

Sources: World Bank Vietnam (2002); Hill (2000); Vu et al. (2001b); STAR (2003).

\footnotetext{
${ }^{2}$ Least squares growth rate in current dollars calculated from data in World Bank Vietnam (1998 and 2001). The 1990-2000 annual average growth rate is 38 percent, but this was from a very low base.

${ }^{3}$ This is well below the share of textiles in total world textile and garment exports of 43 per cent (WTO, 2002). Hill (2000) shows this is low compared with other Asian countries and sees it as a sign of poor performance in textiles.
} 
textile (from 17 per cent in 1995 to 30 per cent in 1999) and garment (from 18 per cent in 1995 to 25 per cent in 1999) production (Vu et al., 2001b). Accurate measures of the scale of the private sector are hard to come by. Nevertheless, the 'household' sector's share of garment output during the 1990s (around 30 per cent) has been higher than its share of total textile production (roughly 17 per cent) (see Vu et al., 2001b). Finally, in both textiles and garments the pre-eminence of SOEs has declined during the 1990s.

State owned T\&G firms are grouped within Vinatex - the national textile and garment corporation. Formed in 1995, Vinatex has 42 member enterprises including all centrally run state-owned textiles and garment firms. As part of the restructuring of SOEs, many are in the process of being corporatized (turned into joint stock companies) while some SOEs have formed joint ventures with foreign partners. Vinatex claims to have 80 percent of Vietnam's capacity in spinning, 50 per cent in weaving, knitting, dyeing and finishing, and 45 per cent in garments. ${ }^{4}$ Amongst Vinatex's member firms, 22 only manufacture garments, while 14 of the 18 textile firms produce garments as well as fabrics. Thus, a significant component of SOEs are vertically integrated, from spinning and weaving to final garment (or home textiles) production. This degree of vertical integration is not seen in the private or FDI segments of the Vietnamese garment and clothing industry.

Vietnam's garment exports were highly concentrated in the late 1990s, with the EU and Japan accounting for 43.3 per cent and 42.2 per cent of exports respectively (Hill, 2000). Thanks to quota allocations for the EU, Vietnamese T\&G exports to the EU rose from US\$ 250 million in 1993 to US\$ 650 million in 1998 (Vu et al., 2001b). In Japan, where Vietnam operates in an 'unrestricted' environment, it has also enjoyed significant export growth. Vietnam's garment exports are also concentrated in terms of product items. In both the EU and Japanese markets, woven (as opposed to knitted) garments account for the bulk of Vietnamese exports (85 per cent of total exports to the EU in 1999 and 78 per cent of exports to Japan in 2000). Within woven garments, the following items dominate: trousers, coats (particularly anoraks), and men and boys shirts. Together, these items account for almost two-thirds of Vietnam's woven garment exports.

Analysis of import trade data for the EU and Japanese markets allows us to observe how Vietnam performs vis-à-vis its leading competitors. ${ }^{5}$ Take men's anoraks. By 1999, Vietnam was the second biggest supplier (after China) of men's and boys' anoraks in both the EU and Japan. Its market share in the EU for this product rose from 0.1 per cent in 1989 to 15.8 per cent in 1999 . Moreover, unlike its major competitors, who saw unit values decline, unit prices for Vietnamese anorak exports to the EU remained stable during the 1990s. Similarly, in Japan it had a 10.1 per cent share of this market, albeit well behind China, which accounted for nearly 80 per cent of anorak sales in Japan. Similarly, in men's cotton shirts Vietnam also did well. While only the 11th biggest supplier of this item to the EU, its market share rose (from 0.4 per cent in 1992 to 3.6 per cent in 1999) while those of larger competitors, such as Hong Kong, Turkey and India, fell. Furthermore, unit values for Vietnamese men's shirts exported to the EU rose at an average of 6.8 per cent a year during the 1990s. In contrast, all leading competitors (with the exception of China, whose

\footnotetext{
${ }^{4}$ Information from pamphlet issued by Vinatex (interview 2001). However, the text of the speech by Bui (2001) on Vinatex's website (www.vinatex.org) suggests Vinatex accounted for only 31 percent of Vietnam's textile and garment production in 2000, and nearly 30 per cent of exports. Vu et al. (2001b, p. 14) cite Vinatex's share of Vietnam's total garment and textile exports as 40 per cent.

${ }^{5}$ Import data for the EU comes from EUROSTAT and is in current $1000 \mathrm{ECU}$ (value) and tonnes (volume). Import data for Japan is from the Japanese government, Ministry of Finance website http://www.mof.go.jp/english/ 1c015f1e.htm, accessed 2002. The data is provided in current 1000 Yen (value) and $\mathrm{kg}$ (volume). We thank Enrique Blanco de Armas for his excellent work in analysing the trade data.
} 
product unit values remained relatively stable) saw the unit values of their products decline. As Kaplinsky and Readman (2000) have argued, rising market shares and rising unit values provides a clear indication of upgrading.

With the USBTA, Vietnamese textile and garment exports to the US rose from $\$ 49$ million in 2001 to an astonishing \$951 million in 2002. Nor was this mere diversion to the US market; total Vietnamese textile and garment exports rose from $\$ 1.96$ billion to $\$ 2.7$ billion over the same period. ${ }^{6}$ By the twelve months ending April 2003, T\&G exports to the US had risen to $\$ 1.69$ billion, of which 95 per cent were of garments. This explosive growth is unlikely to continue at its present pace, however, since MFA-style export quotas to the US were imposed on Vietnam with effect from 1 May 2003. ${ }^{7}$ The export growth to the US is too recent to construct meaningful unit value trends. But, it is clear that there is a continuing specialization on shirts and blouses and on trousers and slacks (all cotton), together making up 49 per cent of the garments total in 2002, while coats of all kinds made up 19 per cent. $^{8}$

\section{VIETNAMESE FIRMS IN GLOBAL VALUE CHAINS}

As the overview shows, Vietnam's T\&G industry has done remarkably well since it began to engage in the early 1990s in competitive global garment markets. There is significant growth in output, a small but not insignificant growth in employment, and clear evidence that Vietnam had gained market share from better established competitors in the demanding European, Japanese, and, more recently, US markets. Given this positive position, we draw on primary evidence from Vietnamese $T \& G$ manufacturers and global buyers, to observe how Vietnam is inserted into global value chains for textiles and garments.

A diverse range of global buyers source from Vietnam. These have distinct relationships and deal with varied types of Vietnamese garment producers. To understand these distinct ties we need first a typology of global buyers who source from Vietnam. These include retailers, producers and traders. Amongst retailers, in the EU, Japan and US markets, are leading international brands from specialist multiples, department stores, supermarkets, discount stores and mail order outlets. Producers who source from Vietnam include international and regional (especially Hong Kong based) garment manufacturers. Finally, traders as category of buyers include leading global traders from Europe, US, Japan and Hong Kong as well as smaller regional traders from Taiwan and South Korea.

A number of the retail buyers source directly from Vietnamese firms, using local representative offices in either Ho Chi Minh City or Hanoi, or through buying offices in Hong Kong - the leading hub in organising the global garment industry. ${ }^{9}$ However, given that Vietnam is both a relatively recent entrant to the global market and that leading brandname retail buyers are keen to reduce their supply base of first-tier vendors, there is a substantial degree of what Gereffi (1999) terms as 'triangular' manufacturing. That is, retail buyers place orders with large regional garment manufacturers with whom they have had a long standing relationships. Many of these manufacturers are headquartered in Hong Kong. The Hong Kong manufacturers organize production through their own FDI or joint

\footnotetext{
${ }^{6}$ See http://just-style.com, accessed May 2003.

${ }^{7}$ For details, see www.ustr.gov/regions/asia-pacific/2003-04-25-Vietnam-textiles-summary.pdf, accessed June 2003.

${ }^{8}$ See http://otexa.ita.doc.gov, accessed September 2003.

${ }^{9}$ On Hong Kong's role as an economic and trading hub, with particular focus on the garment industry, see Berger and Lester (1997) and Enright et al. (1997).
} 
venture facilities in Vietnam or pass on the order to Vietnamese suppliers. This can lower costs of chain governance for the brand retailer.

Similarly, traders play an important role in Vietnam. Many leading retail buyers in the US, for example, relied on traders in Hong Kong (such as Li and Fung) to help develop their Vietnamese supply base and to reduce the transaction costs associated with sourcing from Vietnam. Traders were also very important for the Japanese markets, with leading Japanese trading companies establishing offices in Ho Chi Minh City to service demand from the Japanese garment retail sector. The key role of traders is also borne out by our firm sample. Of the 29 garment manufacturers surveyed, 59 per cent stated that traders were their main buyers. Amongst the subset of nine SOEs and joint venture units interviewed, eight reported traders as their leading buyers. In contrast to the large 'global' traders from Hong Kong and Japan, who tend to source from SOEs, smaller regional traders from Taiwan and South Korea largely deal with small private and household based garment firms in Vietnam and supply regional markets, other developing countries, and lower price segments of markets in the EU and now the US.

Alongside the distinct typology of buyers, there is a sharp differentiation in links with local garment producers. Large SOEs supply the major global markets - thus all five SOEs interviewed were producing for the EU and Japanese markets, while four were also engaged in the US market. Of the fifteen private firms interviewed, only half were producing for the EU market, a third were also engaged in the US market, and only 20 percent manufacturing for the more demanding Japanese market. All the SOEs interviewed and three quarters of the joint venture units surveyed were producing garments for leading brand retailers. In contrast, only one-third of private firms stated that they had undertaken orders for brand outlets, and these were largely for regional and not global brands. SOEs were usually dealing with leading traders, and in some cases directly with leading brand-name retail buyers. Foreign invested garment firms rarely had direct contact with international buyers in Vietnam, since their sales were usually arranged through the foreign principal's head offices in Hong Kong, Taiwan or Korea. In contrast, private enterprises (especially smaller firms) were primarily dependent on small regional traders. Moreover, while private garment units dealt with fewer buyers than SOEs (an average of seven buyers for private firms surveyed compared to over 22 buyers on average for sampled SOEs).

Given the predominance of triangular sourcing - through producers and tradersVietnamese companies were often unaware of the final destinations of their goods. Almost half of the fifteen private firms reported no knowledge of the final market where their garments were sold. Even some SOEs, such as one large garment and textile exporting SOE in Ho Chi Minh City commenting on its ties with South Korean and Taiwanese traders, were unaware of the final sales outlets. Similar comments were made by a state company in a textiles joint venture with a Taiwanese partner who handled the marketing. This distance from the final retailer can have a significant impact on local producers, making it harder for them to acquire market intelligence and to respond rapidly to shifting demands from global buyers and to new fashions. To address this concern, Vinatex had played an important role in introducing buyers to SOEs under its umbrella. Some of the largest state companies had also established links with buyers directly. One large T\&G SOE in Ho Chi Minh City said it had arranged visits from well known US buyers in anticipation of the lowering of import tariffs into the US under the BTA. Direct links with retail buyers also helped producers, largely SOEs, joint venture and FDI units to improve quality through the inspections carried out by the buyers. In several of our interviewed 
state companies, some exporting half or more of their output, international buyers had set up their own offices to advise and oversee on quality.

Despite the diverse types of buyers that Vietnamese T\&G firms deal with, from large global traders to small regional traders, Hong Kong based manufacturers to leading global brands, one aspect that is common is the functions Vietnamese firms undertake. Most Vietnamese garment producers undertake cut-make-trim (CMT) tasks. This constitutes the labour-intensive cutting and tailoring processes as well as packing and (usually) delivery. Firms operating on CMT supply thread while buyers supply fabrics. In functional terms, CMT is the most basic form of garment manufacture, and CMT payments cover labour costs, managerial costs, electricity, trading expenses and the firm's profit margin. According to respondents, CMT rates for men's shirts in Vietnam were roughly in the order of US\$ 0.60 to 0.90 per piece, of which some 50-60 per cent was labour costs. Many buyers expressed an explicit preference for working under CMT arrangements. As the representative of one large US department store, which sourced 60 per cent of the fabrics that were used for its garment products, said this 'strengthens our cost leverage'.

The key value added functions of design, advertising and marketing remain the preserve of the retail buyers, although there are indications that Hong Kong manufacturing firms are being asked to take on some design functions. However, an important function where delegation can and does occur in the value chain is in sourcing of fabrics. Fabrics are critical to the final cost and quality of a garment item. In part, this is often why global buyers seek to retain this function. One form of process upgrading in garment production, therefore, is to move from $\mathrm{CMT}$ to $\mathrm{FOB}^{10}$ production. Under $\mathrm{FOB}$, the garment firm is responsible for obtaining fabrics, with fabrics accounting for between 50-80 per cent of the final FOB price. Their ability to do so is conditioned by the quality and price of domestically produced fabrics available in Vietnam, largely from the SOE and FDI sector, and their ability to source fabrics from abroad on a regular, reliable and cost-efficient basis. In terms of upgrading into FOB, there is a clear bias in favour of SOEs. The majority (over three quarters) of SOEs and joint venture units interviewed were engaged in both CMT and FOB production. In contrast, only 13 percent of private firms had similarly moved up the value chain.

Complaints about the quality of local fabric are common among garment exporters ( $\mathrm{Vu}$ et al., 2001a, p. 21). One study commented on 'the inability of the local textile industry to meet the various demands of foreign buyers for specific fibre content, fabric construction, design, finish and quality at competitive prices' (MPDF, 2000, p. 15). The director of Vinatex stated '.. the textile and garment industry of Vietnam is still less developed, still weak in brand names and design. The limitation in the supply of high quality fabric and accessories has weakened remarkably our competitiveness'. ${ }^{11}$

Discussions with several international buyers in Vietnam partially confirmed this impression. One buyer mentioned the high quality of Vietnamese garment workmanship that led her to source international brand name goods in Vietnam, but that such garments required sophisticated fabric not available locally. Another said many fabric types were still unavailable, such as functional fabrics for work uniforms. However, a third buyer commented that the quality of fabric had improved considerably in the last five years as Korean and Taiwanese investors established both cottons and synthetic fabric production

\footnotetext{
${ }^{10}$ That is, the firm buys or provides the fabric itself and charges a price for the final garment rather than earning only a processing fee. This use - or misuse! — of the term FOB ('free on board') is common in the garment industry.

${ }^{11}$ Undated copy of speech supplied by Vinatex at interview in July 2001. Italics added.
} 
in Vietnam. Interviews with several of the major inward investors in textiles showed all were exporting at least half of their output, either directly or indirectly through sales to garment exporters, the proportion of direct $v s$. indirect varying greatly between producers.

The importance of local textiles is especially significant for integrated SOEs that spin yarn, weave fabrics and stitch garments for export. SOEs exporting garments were able to make fabrics of adequate quality for their own garment exports according to buyers interviewed in Vietnam. An indication of the importance of these indirect exports of fabrics by textile SOES is that 77 per cent of the fabric exports in 2000 of nine leading Vinatex enterprises - which exported on average a third of their fabric output-were made indirectly in the form of garments. ${ }^{12}$

In addition, a number of SOEs interviewed in Ho Chi Minh City stated that attracting CMT work was becoming more difficult as European buyers were perceived as switching their business to firms able to export FOB. Finally, state policy towards the textile industry has stressed the need to increase the domestic content of garment export, using the share of FOB exports in total exports as a crude proxy for local content in garments. ${ }^{13}$ Of Vinatex's total garment exports, 40 percent is on a FOB basis compared with 25 percent for the country as a whole (Bui, 2001). This suggests that the share of FOB in non-Vinatex exports is well under 20 per cent. Thus while state textile companies are exporting garments made from their own fabrics, other companies (both SOEs, and private as well as foreign invested firms) export garments using imported fabric.

Vietnam's T\&G industry has rapidly inserted itself into export garment global value chains. They have been helped in this by the practice of triangular sourcing with foreign traders and garment producers (especially from Hong Kong) playing in leading role in linking Vietnamese producers to global retailers. Yet, ties into value chains are quite distinct. Large SOEs, which have the capacity to undertake large orders and the scope to produce a wider range of garment products, have been better able to attract the higher value chains. In contrast, smaller private firms have tended to be restricted to smaller regional traders and less valuable markets. Moreover, in terms of processes undertaken in garment production, SOEs appear better positioned to upgrade into fabric sourcing and thus access higher rents. Given this uneven experience of insertion into global production, the next section probes the differentiated nature of gains for firms and workers within Vietnam's T\&G sector.

\section{DIFFERENTIATED GAINS}

While Vietnam as a whole has done well in garment exports, the gains from engagement in global markets are differentially distributed. In this section, we focus on this differentiated story - distinguishing between winners and losers at the level of sectors, firms and workers.

Apart from textile SOEs exporting garments made from their own fabrics, Vietnam's garment exporting has been developed largely with imported fabrics. CMT production has meant that fabric sourcing remains in the purview of buyers. But competitive pressures from China, demands from buyers to reduce lead times and the Vietnamese government's aim to raise local content in garment exports will require greater efforts in developing the

\footnotetext{
${ }^{12}$ Based on data supplied in Vinatex (2000).

${ }^{13}$ It is a proxy since garment exporters could purchase imported fabric to export garments FOB. Also, even garments exported FOB with local fabric have an indirect import content from imported cotton etc., and CMT exports have some local content.
} 
textile industry to meet the needs of the export garment sector. T\&G SOEs point the way forward in this, through investments in textile spinning, weaving and dyeing. But this has been done with subsidized state credit unavailable to the private sector. Nevertheless, evidence from buyers point to the rising standards of Vietnamese fabrics, and foreign investments especially by Korean and Taiwanese textiles manufacturers, suggest that the share of local fabric in Vietnamese garment exports is likely to rise. This also suggests that currently dominant practice of CMT manufacturing will also see a growing move to local producers working under FOB terms.

Another aspect of the differentiated gains lies at the level of firms. It is clear that large SOEs have been able to insert themselves into the value chains of leading global buyers. Such firms are able to take on large orders, to manufacture a relatively diverse product range, and to easily meet demands on compliance with global standards, especially labour codes. Thus, there are clear signs that while the numbers of private garment firms are expanding, especially in the south, such producers are unable to access the higher quality and higher value chains. Small private firms often supply smaller regional traders, operate in poorer working conditions, pay lower wages and employ relatively more marginalized workers.

Finally, what have been the impacts of Vietnam's integration into the international economy on textile workers, who appear to be the main losers? As a result of restructuring in textile SOEs to improve competitiveness, Vietnam in the 1990s experienced a 30 percent fall in state textile employment, even though gross output was increasing (GSO, 2000; GSO, 2001). The large contraction in the overall textile workforce is clear from Table 2, down by almost a third during the 1990s. Almost all of the SOEs among our interviewed textile companies in Hanoi and Ho Chi Minh City had reduced their workforce substantially in the early 1990 s, some by over 40 per cent. Only one enterprise

Table 2. Textiles and garments employment and gross output in Vietnam

\begin{tabular}{|c|c|c|c|c|c|c|c|c|c|c|}
\hline & 1990 & 1991 & 1992 & 1993 & 1994 & 1995 & 1996 & 1997 & 1998 & 1999 \\
\hline $\begin{array}{l}\text { Total textile and } \\
\text { garments } \\
\text { employment }\end{array}$ & d 443476 & 408284 & 395062 & 448802 & 513132 & 524846 & 530276 & 504995 & 486385 & 530969 \\
\hline \multicolumn{11}{|l|}{ Textiles } \\
\hline Employment & 306560 & 258889 & 244632 & 260587 & 293480 & 256220 & 247493 & 219846 & 200799 & 212303 \\
\hline Gross output & 4825995 & 4878163 & 5439282 & 5493908 & 6224566 & 6248769 & 6373454 & 7261199 & 8365898 & 8388116 \\
\hline $\begin{array}{l}\text { Output per } \\
\text { worker }\end{array}$ & 15.7 & 18.8 & 22.2 & 21.1 & 21.2 & 24.4 & 25.8 & 33.0 & 41.7 & 39.5 \\
\hline \multicolumn{11}{|l|}{ Garments } \\
\hline Employment & 136916 & 149395 & 150430 & 188215 & 219652 & 268626 & 282783 & 285149 & 285586 & 318666 \\
\hline Gross output & 819469 & 920103 & 1121483 & 1568061 & 2254381 & 2959763 & 3400294 & 4325430 & 4666474 & 5217536 \\
\hline $\begin{array}{l}\text { Output per } \\
\text { worker }\end{array}$ & 6.0 & 6.2 & 7.5 & 8.3 & 10.3 & 11.0 & 12.0 & 15.2 & 16.3 & 16.4 \\
\hline
\end{tabular}

Source: GSO (2000).

All output figures are in VND million at constant 1994 prices.

1990-94 figures originally at constant 1989 prices have been converted to 1994 prices. Note that the industrial classifications change between 1994 and 1995, though it is assumed here that textiles and garments are not greatly affected by the change.

Note that garment output figures are subject to severe difficulties and may be understated several fold. Converting the output figures for 1994 all-Vietnam garment production from dong into US dollars gives a figure that is less than half the value of exports! The most likely explanation is that CMT garment gross output is recorded as the processing fee alone. This is supported by the fact the 'receipts from industrial services' generated 43 per cent of 1998 gross garment output in the 17 most industrialised provinces (GSO, 2000). The corresponding figure for textiles was close to zero. 
Table 3. Employment and output per worker (VND million)

\begin{tabular}{lcccc}
\hline & 1995 & 1997 & 1998 & 1999 \\
\hline Textiles & & & & \\
State sector-employment & 83975 & 71620 & 69856 & 73455 \\
State sector-output per worker & $\mathbf{4 1 . 8}$ & $\mathbf{5 6 . 1}$ & $\mathbf{6 0 . 2}$ & $\mathbf{6 2 . 0}$ \\
Non-state domestic sector-employment & 160944 & 129010 & 110115 & 118041 \\
Non-state domestic sector-output per worker & $\mathbf{9 . 9}$ & $\mathbf{1 3 . 8}$ & $\mathbf{1 7 . 2}$ & $\mathbf{1 7 . 5}$ \\
Foreign sector-employment & 11301 & 19216 & 20828 & 20807 \\
Foreign sector-output per worker & $\mathbf{9 4 . 7}$ & $\mathbf{7 5 . 8}$ & $\mathbf{1 0 8 . 7}$ & $\mathbf{8 4 . 8}$ \\
Garments & & & & \\
State sector-employment & 71493 & 86053 & 91803 & 94050 \\
State sector-output per worker & $\mathbf{1 4 . 3}$ & $\mathbf{1 7 . 3}$ & $\mathbf{1 6 . 6}$ & $\mathbf{1 8 . 5}$ \\
Non-state domestic sector-employment & 182697 & 167527 & 159526 & 188805 \\
Non-state domestic sector-output per worker & $\mathbf{7 . 6}$ & $\mathbf{1 1 . 6}$ & $\mathbf{1 3 . 1}$ & $\mathbf{1 2 . 0}$ \\
Foreign sector-employment & 14436 & 31569 & 34257 & 35811 \\
Foreign sector-output per worker & $\mathbf{3 7 . 1}$ & $\mathbf{2 8 . 1}$ & $\mathbf{3 0 . 9}$ & $\mathbf{3 3 . 9}$ \\
\hline
\end{tabular}

Source: GSO (2000) for employment, but output data are not broken down by ownership.

GSO (2001) for output data in constant 1994 prices, broken down by ownership, which gives data for 1995, 1998, 1999, 2000, and provisional 2001 (not shown), but does not give employment by ownership. 1997 figures are from the 2000 edition.

Total output values for each year for textiles and garments are approximately the same in both sources, even though the descriptions of ownership by sector differ.

interviewed felt-or at least was prepared to say-it still had an excessively large workforce. Much of the reduction in workforce had been organized through early retirements. In several cases enterprises spoke of reducing their workforce and subsequently building it up to some extent with new and better-educated workers. Sometimes workers were induced to retire by the enterprise offering jobs to their children. Where workers were retrenched, compensation was paid, the amount depending on the length of a worker's service. In recent years, Vinatex has helped with this compensation. A virtually universal response among SOEs that had retrenched some of their workers was that production had increased while the workforce had been reduced. This impression is strongly supported by the large rise in (gross) labour productivity over the 1990s, as shown in Table 3. The rising gross labour productivity has been accompanied by rising wages. Using data obtained from a selection of sample textile enterprises in Ho Chi Minh City shows that in all but one case - a city owned SOE known to be having problems - real wages rose substantially during the 1990s. Since most firms made garments as well as textiles, the wage figures suggest garment workers' wages rose too in the SOE sector.

The substantial retrenchments that have taken place in textile SOEs have mainly been of older workers with poor health and lower educational levels. Only 30 per cent of the retrenched workers studied in our companion study of textile workers' households had been able to find another formal sector job. However, a combination of informal sector earnings, early retirement pensions and retrenchment allowances meant that our retrenched workers had on average a monthly per capita income of about double the 2001 official urban poverty line of VND150000 set out in the CPRGS (Nguyen et al., 2003).

Vietnam's export garment sector has grown more rapidly in recent years than its textile industry, and the fall in textile employment has been accompanied by an even greater rise in garment employment, both in the state sector and even more in the co-operative and private sectors (GSO, 2000; GSO, 2001). The rise is garment employment is even more 
Table 4. Employment 1989 and 1999

\begin{tabular}{lcc}
\hline & 1989 & 1999 \\
\hline Textiles & 335463 ('weaving') & 209602 \\
Garments & 364807 & 761815 \\
\hline
\end{tabular}

Source: Population censuses 1989 and 1999 from GSO-IID (1998 and 2001), on employed population aged 13 and over.

striking using the population census statistics for 1989 and 1999 (Table 4), which suggest that garment household employment is not fully recorded by the Tables 2 and 3 sources.

There has also been a sharp apparent rise in garment labour productivity in total (Table 2) and both the state and non-state sectors (Table 3), although as explained in Table 2, this should be treated with caution because of severe deficiencies in the garment production statistics. Much of the employment gains in export garment production have been captured by women, including migrants from poorer regions of the country. Moreover, garment workers in the SOE sector have particularly gained. However, such workers, many of whom are women, have residency status in the main urban centres and the requisite levels of secondary schooling to gain access to SOE jobs. Migrants from poorer regions, who often lack residency rights or the requisite education standards, are thus forced to seek work in smaller private garment enterprises, especially within the burgeoning informal sector.

\section{CONCLUSIONS}

This paper set out to assess how globalization has affected the Vietnamese textile and garments industry. Vietnam has emerged during the 1990s as a significant garment supplier to quality conscious markets in the EU, Japan and now the US. We have argued that it is the nature of insertion within global value chains that influences Vietnam's success. Moreover, such insertions have led to differentiated gains from global engagement for firms and workers.

Vietnamese T\&G firms supply a range of global buyers, from leading brand name retailers to small regional traders. The nature of ties with buyers varies by types of firms. SOEs with substantial capacity to supply a diverse product range and to take on large orders are able to cater to higher quality lead buyers. In contrast, smaller private firms supply smaller volumes to lower quality markets through regional traders. Many T\&G SOEs have been able to upgrade, especially in textile production, through subsidised state credit and are increasingly integrating Vietnamese fabrics into their garment exports. Thus, we see for some SOEs a shift up the value chain from CMT to FOB production.

These differentiated value chain ties have implications for $T \& G$ workers. In Vietnam there has been substantial contraction in formal-sector and household textile employment. The formal sector contraction has been part of the restructuring of state owned enterprises. More state enterprise reform is planned, including further equitisations. The fall in formal textile employment has been more than matched by a rise in garment employment. This is especially so in private garment firms, many of whom heavily rely on migrant women workers. The negative impact of trade liberalization in textiles has been on employment not wages. Although workers in textile SOEs may be subject to more discipline than in the past, their higher productivity has been accompanied by higher wages. 
Thus, in the matrix of winners and losers, while garment workers have gained through employment, it is those who work in SOEs that have especially benefited. The gains at the level of SOEs lies in their ability to upgrade thanks to state subsidised credit, their ability to undertake orders for leading global buyers, and their access to the know-how that such buyers impart to their suppliers. This leaves us with two key sets of questions for further research. First, how are Vietnamese firms adapting to global challenges? In particular, how does this vary by types of firms and by type of challenge? ${ }^{14}$ Second, what are the poverty consequences of this, especially at the level of workers' household livelihoods? ${ }^{15}$

\section{ACKNOWLEDGEMENTS}

This paper has been prepared as part of a research programme on globalization and poverty funded by the Department for International Development of the UK government. The authors are especially grateful to respondents interviewed in Vietnam, Hong Kong, China and the UK. We are grateful to Rhys Jenkins, Myriam Velia and a referee for comments, but the usual disclaimer applies.

\section{REFERENCES}

Bair J, Gereffi G. 2001. Local clusters in global chains: the causes and consequences of export dynamism in Torreon's blue jeans industry. World Development 29(11): 1885-1903.

Berger S, Lester RK. 1997. Made by Hong Kong. Oxford University Press: New York.

Bui Xuan K. 2001. Development for Vietnam textile and garment industry, seminar speech on 3 April in Hanoi by General Director of Vinatex. on Vinatex website www.vinatex.com, accessed April 2002).

CPRGS. 2002. The Comprehensive Poverty Reduction and Growth Strategy. Socialist Republic of Vietnam: Hanoi.

DfID. 2000. Eliminating world poverty: making globalisation work for the Poor. UK White Paper on International Development. Department for International Development: London.

Enright MJ, Scott EE, Dodwell DD. 1997. The Hong Kong Advantage. Oxford University Press: New York.

Gereffi G. 1999. International trade and industrial upgrading in the apparel commodity chain. Journal of International Economics 48: 37-70.

GSO. 2000. Analysing the Results of the Industrial Survey of Vietnam-1999. General Statistics Office of Vietnam, Statistical Publishing House: Hanoi.

GSO. 2001. Vietnam Statistical Yearbook, 2001. General Statistics Office of Vietnam, Statistical Publishing House: Hanoi.

GSO-IID. 1998. Major Social and Economic Information Obtained from the Large Scale Surveys in Period of 1990-96. General Statistics Office of Vietnam-Integrated and Information Department, Statistical Publishing House: Hanoi.

GSO-IID. 2001. Major Socio- Economic Information Obtained from Ten Large Scale Surveys in Period of 1998-2000. General Statistics Office of Vietnam - Integrated and Information Department, Statistical Publishing House: Hanoi.

\footnotetext{
${ }^{14}$ See the further paper by Nadvi and Thoburn (forthcoming).

${ }^{15}$ This is traced in the project separately for textile and for garment workers, as textile employment has contracted while garment employment has expanded. For summaries of preliminary results, see Thoburn and Jones (2002).
} 
Hill H. 2000. Export success against the odds: a Vietnamese case study. World Development 28(2): 283-300.

Kaplinsky R, Readman J. 2000. Globalisation and upgrading: what can, and cannot, be learnt from international trade statistics in the wood furniture sector. (mimeo) Institute of Development Studies, Brighton, UK.

MPDF. 2000. Vietnam's Garment Industry: Moving up the Value Chain. Mekong Project Development Facility: Hanoi.

Nadvi K, Thoburn JT. Forthcoming. Challenges to Vietnamese firms in the world garment and textile value chain, and the implications for alleviating poverty. Journal of the Asia Pacific Economy.

Nguyen TH, Sutherland K, Thoburn JT. 2003. Globalization and the impact of restructuring in the textiles sector on households in Vietnam. Globalisation, Production and Poverty Discussion Paper No. 12. Overseas Development Group, University of East Anglia: Norwich (to appear on www.gapresearch.org).

STAR. 2003. An Assessment of the Economic Impact of the United States-Vietnam Bilateral Trade Agreement: Annual Economic Report for 2002. Support for Trade Acceleration (STAR) project and Central Institute for Economic Management: Hanoi.

Stiglitz JE. 2002. Globalisation and its Discontents. Allen Lane: London.

Thoburn JT, Jones R. 2002. Globalisation and poverty in Vietnam: an overview of ten papers in the DfID Globalisation and Poverty research programme. (available at www.gapresearch.org/ Povertyglobalisationoverview.pdf, accessed September 2003).

Vinatex. 2000. Summarising report on the production and trading situation in 2000. (In Vietnamese): Hanoi.

Vu Quoc Huy, Vi Tri Thanh, Nguyen Thang, Cu Chi Loi, Nguyen Thi Thanh Ha, Nguyen Van Tien. 2001a. Trade Liberalisation and Competitiveness of Selected Industries in Vietnam Project: Analysis of Qualitative Factors affecting Competitiveness of Textile and Garment Firms in Vietnam. Institute of Economics, Hanoi/International Development Research Center, Canada: Hanoi.

Vu Quoc Huy, Vi Tri Thanh, Nguyen Thang, Cu Chi Loi, Nguyen Thi Thanh Ha, Nguyen Van Tien. 2001b. Trade Liberalisation and Competitiveness of Selected Industries in Vietnam Project: Textile and Garment Industry in Vietnam. Institute of Economics, Hanoi/International Development Research Center, Canada: Hanoi.

World Bank Vietnam. 1998. Vietnam: Rising to the Challenge: An Economic Report. June 18-19: Hanoi.

World Bank Vietnam. 2000. Vietnam 2010, Entering the 21st Century: Vietnam Development Report, 2001. Pillars of Development. World Bank Vietnam: Hanoi.

World Bank Vietnam. 2001. Implementing reforms for faster growth and poverty reduction: Vietnam Development Report 2002. World Bank: Hanoi.

World Bank Vietnam. 2002. Vietnam: Delivering on its Promise. Development Report 2003. World Bank: Hanoi.

WTO. 2002. International Trade Statistics 2002. World Trade Organisation: Geneva (www.wto.org, accessed August 2003). 